\title{
Hypovirulent isolates of Colletotrichum gloeosporioides induce resistance to anthracnose in detached mango fruits and seedlings ${ }^{1,2}$
}

\author{
Julissa Colón-Garay ${ }^{3}$,Lydia I. Rivera-Vargas ${ }^{4}$, \\ Robert McGovern ${ }^{5}$ and Rocío del P. Rodríguez ${ }^{6}$
}

J. Agric. Univ. P.R. 86(1-2):55-64 (2002)

\begin{abstract}
Colletotrichum gloeosporioides [(Penz.) Penz. \& Sacc.] causes anthracnose in various tropical crops, including mango (Mangifera indica L.). In Puerto Rico, estimated losses in mango fruits are as high as $75 \%$. Intensive chemical applications used to control this disease have resulted in fungicide resistance and potential environmental pollution. An alternative control could be inducing resistance in mango with hypovirulent isolates of C. gloeosporioides. Hypovirulent (HV) mutants were obtained by conidial mutagenesis using ultraviolet light. Mycelial plugs (4 mm) of HV mutants were used to inoculate the surface of detached mango fruits, either 24 or $120 \mathrm{~h}$ previous to the virulent isolate inoculation. Fruits were kept in humid chambers (i.e., $100 \% \mathrm{RH}$ ). Lesion size was measured eight and 14 days after inoculation with the virulent isolate. Mango seedlings were inoculated with the HV mutants, as described above, $120 \mathrm{~h}$ prior to the virulent isolate inoculation and kept under shade-house conditions. Lesion size was measured four and 10 days after inoculation with the virulent isolate. Fourteen days after inoculation, three HV mutants reduced lesion size in detached fruits by $50 \%$. Locally induced resistance (in situ) was observed in middle leaves of mango seedlings. All three HV mutants tested reduced lesion development in middle leaves of mango seedlings 10 days after inoculation. Hypovirulent isolates HV-49 and HV-165 induced systemic resistance to the upper leaves of the plant. The HV mutants appeared to inhibit pathogen development by activating defense mechanisms in mango fruits and seedlings.
\end{abstract}

${ }^{1}$ Manuscript submitted to Editorial Board 21 November 2001.

${ }^{2}$ This research was supported by a USDA T-STAR grant 76 in collaboration with the Department of Plant Pathology, University of Florida in Bradenton, and the Department of Crop Protection, University of Puerto Rico, Mayagüez Campus. The authors thank all reviewers for their time and interest.

${ }^{3}$ Former Graduate Student, Dept. of Crop Protection, P.O. Box 9030, University of Puerto Rico, Mayagüez, PR 00681-9030.

${ }^{4}$ Associate Professor, Dept. of Crop Protection, P.O. Box 9030, University of Puerto Rico, Mayagüez, PR 00681-9030.

${ }^{5}$ Associate Professor, Dept. Plant Pathology, GCREC, University of Florida, Bradenton, FL 34203.

${ }^{6}$ Plant Pathologist, Dept. of Crop Protection, P.O. Box 9030, University of Puerto Rico, Mayagüez, PR 00681-9030. 
Key words: anthracnose, Colletotrichum gloeosporioides, mango, induced resistance, hypovirulence

\section{RESUMEN}

Aislados hipovirulentos de Colletotrichum gloeosporioides inducen resistencia a la antracnosis en frutas desprendidas y arbolitos de mangó

Colletotrichum gloeosporioides [(Penz.) Penz. \& Sacc.] es el causante de la antracnosis en varios cultivos tropicales incluyendo el mangó (Mangifera indica L.). En Puerto Rico, las pérdidas estimadas en las frutas de mangó pueden ser hasta $75 \%$. Las aplicaciones intensas de agentes químicos que se utilizan en el control de esta enfermedad han resultado en el desarrollo de resistencia a fungicidas y pueden contaminar el ambiente. Un método alterno de control puede ser induciendo resistencia en mangó con aislados hipovirulentos de $C$. gloeosporioides. Se obtuvieron mutantes hipovirulentos (HV) mediante mutagénesis de la conidia utilizando la luz ultravioleta. Se utilizaron discos de micelio (4 mm) de los mutantes HV para inocular la superficie de frutas desprendidas de mangó 24 ó 120 h previo a la inoculación con el aislado virulento. Las frutas se mantuvieron en cámaras húmedas (i.e., $100 \%$ HR). Se midió el tamaño de las lesiones a los ocho y 14 días después de la inoculación del aislado virulento. Se inocularon arbolitos de mangó con los mutantes HV, como descrito anteriormente $120 \mathrm{~h}$ previo a la inoculación del aislado virulento y se mantuvieron en condiciones de umbráculo. Se midió el tamaño de las lesiones a los cuatro y 10 días después de la inoculación del aislado virulento. Catorce días después de la inoculación, tres mutantes hipovirulentos redujeron el tamaño de la lesión hasta un $50 \%$ en frutas desprendidas. Se observó inducción de resistencia local (in situ) en las hojas centrales de los arbolitos de mangó. Los tres mutantes hipovirulentos evaluados redujeron el desarrollo de la lesión en las hojas centrales de los arbolitos de mangó, diez días después de la inoculación. Los aislados HV-49 y HV-165 indujeron resistencia sistémica en las hojas superiores de la planta. Los mutantes HV aparentan inhibir el desarrollo del patógeno activando mecanismos de defensa en las frutas y en los arbolitos de mangó.

\section{INTRODUCTION}

Colletotrichum gloeosporioides [(Penz.) Penz. \& Sacc.] causes anthracnose in many important crops including mango (Mangifera indica L.) (Arauz, 2000; Bailey and Jeger, 1992). Losses result from damage to fruits, leaves and flowers. Crops such as mango, avocado, papaya, guava and other tropical fruits are seriously infected under field conditions in which high temperatures and humidity prevail (Arauz, 2000; Freeman, 2000). World wide the incidence of anthracnose can reach $100 \%$ in fruits produced under similar conditions (Arauz, 2000). Puerto Rico's wet tropical conditions are conducive to severe Colletotrichum spp. infections in a variety of crops (Colón Garay and Rivera Vargas, 1997a, b, 1998).

Mango is the most economically important fruit in Puerto Rico, contributing a substantial $\$ 19.91$ million U.S. dollars to the island's agricultural annual gross income (Puerto Rico's Department of Agriculture, 2000). Estimated losses caused by anthracnose are as high as 75\% for 
domestic consumption and 50\% for fresh fruit export (E. Toro, Former Fruit Specialist, Agricultural Extension Service, personal communication). Chemical applications are commonly used to control this disease worldwide. However, these chemicals have induced fungicide resistance in the pathogen and caused pollution in residential areas (Freeman et al., 1998). Thus, it is important to evaluate new methods of control for this pathogen in order to reduce disease development, to eliminate environmental pollution, and to increase the quantity and quality of disease-free fruit available for local consumers and export.

An alternative control could be a natural phenomenon known as induced resistance or "plant immunization" against pathogens, a control which has been described extensively (Karba and Kuc, 1999). This method relies on the activation of a variety of defense responses at the cellular level. The induction of resistance in plant organs remote from the inoculation site results from the translocation of signals produced at the inoculation site. The activation of multiple plant defense mechanisms can include the production of antifungal enzymes, accumulation of phytoalexins, formation of protective barriers, all orchestrated to protect plants against a wide variety of pathogens (Hammerschmidt and Kuc, 1982; Prusky et al., 2000; Sticher et al., 1997; Wei et al., 1996).

Recently, Yakoby et al. (2001) developed reduced pathogenicity mutants of C. gloeosporioides by insertional mutagenesis using restriction enzyme mediated integration (REMI) transformation. The mutants were used to increase avocado natural resistance mechanisms as a way to reduce post-harvest disease severity. In our studies several C. gloeoesporioides hypovirulent mutants were developed by conidial mutagenesis. These were evaluated for their ability to induce resistance to anthracnose in detached mango fruits and seedlings.

\section{MATERIALS AND METHODS}

\section{Fungal Isolates}

Colletotrichum gloeosporioides was isolated from natural anthracnose lesions in mango fruits and leaves. All isolates were maintained in potato dextrose agar, acidified with $25 \%$ lactic acid (APDA) at room temperature.

\section{UV Light Mutagenesis}

Previous studies, in which UV radiation, nitrosoguanidine, nitrous acid or ethylmethane sulphonate were used for C. gloeosporioides conidia mutagenesis, have shown that UV light treatment produced the highest amount of single spore survivors, and a higher percentage 
of mutation rate (Dickman and Patil, 1986). Therefore, conidial suspensions ( $5 \times 10^{6}$ conidia per milliliter) of a virulent $C$. gloeosporioides isolate were exposed for $240 \mathrm{sec}$ to UV light ( $30 \mathrm{~W}$ germicidal lamp, General Electric FG30T87) at a distance of $35 \mathrm{~cm}$ from the light source (Dickman and Patil, 1986). Non-UV light exposed conidia were used as control. One milliliter of each mutated conidial suspension was placed in water agar in order to obtain viable single spore colonies.

\section{Hypovirulence Screening}

Seven-day-old mycelial disks $(4 \mathrm{~mm})$ from mutated C. gloeosporioides isolates grown on APDA were used to inoculate superficially disinfested detached mango fruits (cv. Keitt) after wounding. Wounds were inflicted by pressing into mango tissues three pin tips embedded in a cork plug. Inoculum was placed on detached fruits at eight different points, separated from each other by $3.75 \mathrm{~cm}$. Controls were inoculated with APDA disks after wounding. Eight fruits (four per each mutant isolate and four controls) were incubated in $91.44 \times 30.48-\mathrm{cm}$ plastic boxes under high humidity (i.e., $100 \%$ ) at $25^{\circ} \mathrm{C}$ for seven days. High humidity was maintained by adding sterile distilled water to the bottom of the box every other day. Lesions were measured (mm) up to seven days after inoculation.

Isolates showing lesions of $3.0 \mathrm{~mm}$ or less on detached mango fruits were characterized as hypovirulent. Hypovirulence tests were repeated twice on mango fruit pieces $\left(2 \times 4 \mathrm{~cm}^{2}\right)$ to confirm observations and evaluate stability of the isolates. The stability of hypovirulent isolates was evaluated by inoculating the isolates on detached mango fruits and leaves.

\section{Detached Fruit Studies}

Nine HV mutants were selected for inoculating detached mango fruits, 24 or $120 \mathrm{~h}$ prior to the inoculation with a virulent C. gloeosporioides isolate, after wounding. Details on fungal culture, inoculation methods and humid chamber conditions have been described previously. Eight fruits (four per each mutant isolate and four controls) were placed in a plastic box under high humidity (i.e., $100 \%$ and $25^{\circ} \mathrm{C}$ ), as previously described. The HV isolate was inoculated at eight different sites to guarantee its establishment on mango tissues, whereas the vir-

\footnotetext{
${ }^{7}$ Trade names in this publication are used only to provide specific information. Mention of a trade name does not constitute a warranty of equipment or materials by the Agricultural Experiment Station of the University of Puerto Rico, nor is this mention a statement of preference over other equipments or materials.
} 
ulent isolate was inoculated twice on each fruit. Control treatments consisted of detached fruits inoculated with APDA disks after wounding. Lesions were measured $(\mathrm{mm})$, eight and 14 days after inoculation. Percentage of reduction in lesion size was calculated as follows:

$$
\text { Percentage }=\left[\frac{\text { Lesion size of virulent }+\mathrm{HV}}{\text { Lesion size of virulent }+ \text { control }} \times 100\right]
$$

Data were tabulated and analyzed for further experiments on mango seedlings.

\section{Seedling Studies}

Three-month-old mango seedlings (cv. Keitt grafted on cv. Columbus Kidney) were used to evaluate the induction of systemic resistance by hypovirulent $C$. gloeosporioides mutants under shade-house conditions. Seedlings were placed in a walk-in humid chamber $(18 \times 30 \times 30$ $\mathrm{m})$ at $100 \% \mathrm{RH}$ and $26^{\circ} \mathrm{C}$ for 10 days. To investigate the translocation of the induced signal, leaves were selected between the $3 \mathrm{rd}$ and 6 th nodes of the seedling. Three leaves, from the lower, middle and upper parts of the seedling, were selected for the experiment. Three mutants, HV-49, HV-52 and HV-165, were selected from previous evaluations on detached fruits. Details of fungal culture and inoculation method were as previously described.

Each of the three HV mutants and controls (APDA disks) was inoculated only on the central leaf at ten different sites, after wounding. Colletotrichum gloeosporioides virulent isolate was inoculated onto the lower, middle and upper leaves of the plant, five days after HV inoculation at four different points, after wounding. Lesion development was measured four and 10 days after treatment. A randomized complete block design with six individual seedlings per $\mathrm{HV}$ isolate or control was used. Least significant difference [LSD $(\alpha=0.05)$ ] was used to differentiate among control and HV isolates.

\section{RESULTS AND DISCUSSION}

\section{Mutagenesis and Hypovirulence Screening}

Only $5 \%$ of mutated conidia survived exposure to UV for $240 \mathrm{sec}$. Of these, $29 \%$ showed weak colonies with very slow growth and did not survive screening procedures. Sixty colonies from mutated isolates were selected for hypovirulence screening tests. Only 27\% (16 isolates) of selected $C$. gloeosporioides treated with UV light caused lesions ranging from 0 to $3 \mathrm{~mm}$ after inoculation on detached mango fruits and were con- 
sidered hypovirulent. Of these, seven isolates were transitory hypovirulent or unstable, producing bigger lesions after a second screening on mango fruits and leaves. Nine HV mutants were selected for further testing in the induction of resistance on detached mango fruits.

\section{Detached Fruits}

Several HV isolates inoculated on detached mango fruits showed more than $40 \%$ reduction in lesion size caused by virulent isolates. Hypovirulent isolates $4,49,52$ and 67 were effective in limiting lesion development (Table 1). Hypovirulent isolates 4 and 52 reduced lesion size more than $40 \%$ eight days after virulent isolate inoculation on mango tissues. Furthermore, HV isolates 49, 52 and 67 reduced lesion size more than $48 \% 14$ days after inoculation on mango tissues. These results were similar to those obtained by Prusky et al. (1994) using a non-pathogenic isolate of C. magna in avocado. A significant delay in avocado fruit decay development was observed when the non-pathogenic isolate was inoculated prior or after the pathogen, C. gloeosporioides. After eight days, they observed a reduction in fruit decay and lesion size.

TABLE 1.-Mean lesion size $(\mathrm{mm})$ caused by virulent $\mathrm{C}$. gloeosporioides isolates in detached mango fruits after inoculation with hypovirulent $(H V)$ isolates.

\begin{tabular}{|c|c|c|c|c|c|c|c|c|}
\hline \multirow[b]{2}{*}{ Days } & \multicolumn{2}{|c|}{ HV } & \multicolumn{2}{|c|}{ Virulent $+\mathrm{HV}$} & \multicolumn{2}{|c|}{$\begin{array}{l}\text { Virulent + } \\
\text { Control }^{1}\end{array}$} & \multicolumn{2}{|c|}{$\begin{array}{l}\text { Reduction in } \\
\text { lesion size (\%) }\end{array}$} \\
\hline & 8 & 14 & 8 & 14 & 8 & 14 & 8 & 14 \\
\hline \multicolumn{9}{|l|}{ Isolates } \\
\hline $\mathrm{HV}-4^{2 /}$ & 4.80 & 13.0 & 3.25 & 19.10 & 5.50 & 18.30 & 41 & $0^{4}$ \\
\hline HV-18 & 5.00 & 9.25 & 5.75 & 6.50 & 5.00 & 8.25 & $0^{4}$ & 21 \\
\hline $\mathrm{HV}-51^{2 \prime}$ & 4.70 & 5.00 & 5.80 & 11.40 & 6.30 & 12.60 & 8 & 10 \\
\hline $\mathrm{HV}-52^{2 t}$ & 2.50 & 8.00 & 3.25 & 7.30 & 5.60 & 14.00 & 42 & 48 \\
\hline HV- $49^{3 \prime}$ & 1.60 & 3.20 & 8.50 & 12.60 & 12.30 & 25.00 & 31 & 50 \\
\hline $\mathrm{HV}-67^{3 \prime}$ & 8.20 & 8.75 & 8.00 & 9.30 & 9.20 & 21.25 & 13 & 56 \\
\hline HV-165 & 0.50 & 1.50 & 9.75 & 25.00 & 10.60 & 10.80 & 8 & $0^{4}$ \\
\hline HV- $61^{3 \prime}$ & 5.25 & 6.20 & 6.40 & 9.25 & 7.80 & 12.25 & 18 & 25 \\
\hline HV- $84^{3 /}$ & 7.00 & 7.80 & 8.40 & 12.50 & 8.20 & 18.75 & $0^{4}$ & 33 \\
\hline
\end{tabular}

${ }^{1}$ Control consisted of APDA disks.

${ }^{2}$ Fruits were inoculated with mycelial disks of virulent isolate, 120 hours after $\mathrm{HV}$ treatment.

${ }^{3}$ Fruits were inoculated with mycelial disks of virulent isolate, 24 hours after HV treatment.

${ }^{4}$ Lesion size in HV treated detached fruits was greater than in non-treated. 
Of all the HV isolates examined, only two isolates remained hypovirulent 14 days after inoculation on detached mango fruits: HV-49 and HV165 (Table 1). Seven of them were transitory hypovirulent, causing lesions larger than $3 \mathrm{~mm}$ on detached mango fruits. Some HV isolates increased lesion size or did not have a dramatic effect on lesion size reduction on detached mango fruits (Table 1). Only three isolates caused lesions smaller than $3 \mathrm{~mm}$, eight days after inoculation. These were isolates HV-52, HV-49 and HV-165 (Table 1). These three HV isolates were selected for further experimentation with mango seedlings and represented only $5 \%$ of all C. gloeosporioides mutated isolates evaluated for hypovirulence. Even though isolate HV-165 did not show induction of resistance on detached fruits, it was selected to be tested on mango seedlings because of its stability as a hypovirulent mutant.

\section{Seedling Studies}

Significant differences were observed in lesion development among selected leaves after their being challenged with HV isolates (Table 2). Locally induced resistance (in situ), as described by Kloepper et al. (1992), was observed in middle leaves, which showed reduced mean lesion size compared to lesion sizes of upper and lower leaves on the same plant. All three HV isolates tested reduced lesion development on middle leaves of 3-month-old mango seedlings 10 days after inoculation. For example, HV-52 reduced lesion size by $63 \%$ and $37 \%$ in middle leaves four or 10 days after inoculation, respectively. Mean lesion size

TABLE 2.-Mean lesion size $(\mathrm{mm})$ caused by a virulent $\mathrm{C}$. gloeosporioides isolate on mango leaves from upper, middle and lower parts of the seedlings. Lesions were measured four or 10 days after inoculation with a control or hypovirulent isolates: $H V-52, H V-49$ and HV-165.

\begin{tabular}{|c|c|c|c|c|c|c|}
\hline \multirow[b]{3}{*}{ Days } & \multicolumn{6}{|c|}{ Mean lesion size per leaf location $(\mathrm{mm})^{1}$} \\
\hline & \multicolumn{2}{|c|}{ Upper } & \multicolumn{2}{|c|}{ Middle } & \multicolumn{2}{|c|}{ Lower } \\
\hline & 4 & 10 & 4 & 10 & 4 & 10 \\
\hline \multicolumn{7}{|l|}{ Treatments } \\
\hline Control $^{2}$ & 4.75 & 10.50 & 4.04 & 10.30 & 3.63 & 10.50 \\
\hline HV-52 & 3.71 & 9.50 & 1.63 & 6.00 & 3.84 & 8.83 \\
\hline HV-49 & 3.79 & 7.75 & 2.96 & 6.66 & 3.50 & 8.00 \\
\hline HV-165 & 3.42 & 4.30 & 2.75 & 4.50 & 3.50 & 6.00 \\
\hline
\end{tabular}

${ }^{1}$ Mean of six plants. LSD (Least Significance Differences) at $\mathrm{P}=0.05$ are 1.721 for four days and 2.639 for 10 days to compare any two treatment combination means (leaf $\times$ isolate).

${ }^{2}$ Middle leaves of controls were inoculated with APDA disks instead of HV isolate. 
on middle leaves was statistically different from those on upper and lower leaves in mango seedlings treated with this isolate.

Hypovirulent isolates 49 and 165 showed significantly smaller mean lesion size on middle and upper leaves when compared to that of control treatments 10 days after inoculation. Of all HV isolates tested, HV-165 showed the greatest reduction in mean lesion size (40 and 58\%) 10 days after inoculation on upper and central leaves, respectively, when compared to lesion size in controls (Table 2). These findings suggest induced systemic protection to the upper part of the plant against virulent $C$. gloeosporioides isolate (Kloepper et al., 1992). Apparently an inducing signal moves upward through the vascular tissue. This is the first report in which $C$. gloeosporioides hypovirulent mutants were used to induce systemic resistance in three-month-old mango seedlings.

In mango, Droby et al. $(1986,1987)$, showed that antifungal resorcinols can be induced to accumulate in the fruit, thus conferring resistance to the fungal pathogen Alternaria alternata (Fr.) Kreissler. The antifungal resorcinol occurred at fungitoxic levels in the peel of unripe mango, and as resorcinols concentration decreased during ripening, fruits became susceptible. (Prusky and Keen, 1993; Droby et al., 1986). In addition, they reported an increase in the activity of a phenylalanine ammonia lyase (PAL) in the flesh of mango fruits as the result of peeling (Droby et al., 1987). This enzyme has been related to the production of phytoalexins and other important phenolic compounds involved in defense mechanisms in plants (Anderson, 1991).

Triterpenoids, resins, essential oils of variable compositions and a diverse group of phenolic compounds, in addition to the resorcinols accumulated in vacuoles, have been reported in mango (Hegnauer, 1993). Therefore, several lines of evidence suggested that antifungal compounds might be involved in mango resistance to fungal pathogens. However, other mechanisms such as oxidation of endogenous phenols, the production of de novo monomers and polymeric phenols, pathogenesis related proteins and reactive oxygen species might be involved in mango resistance to pathogens (Hammond-Kosack and Jones, 1996). Hypovirulent mutants may have inhibited pathogen development by activating diverse defense mechanisms in mango fruits and seedlings.

However, there are important aspects to be considered in future experiments dealing with the induction of resistance in mango using hypovirulent mutants. Host plant factors such as: (1) age of seedlings, (2) leaf age, and (3) mango cultivar are likely to influence the success of pathogen establishment. Further, C. gloeosporioides' virulence and the stability of different mutant isolates are likely as important determinants in this interaction. Several examples in our study provide insights into the importance of these factors. 
For example, rapid and unchecked growth of virulent isolates in control leaves caused premature leaf abscission, and thus limited our observation period. Whereas control leaves (i.e., without hypovirulent isolate) invariably abscised within 10 days of inoculation, this abscission was never observed in hypovirulent-protected leaves, which remained attached for longer periods.

Our choice of mango cultivar may also have influenced our results. Keitt, our choice mango cultivar, is the most widely used export cultivar in Puerto Rico, and is also known to be less susceptible to anthracnose than other important cultivars, such as Irwin, Kent, or Edward (Ploetz, 1994). A different choice of mango cultivar would perhaps better illustrate hypovirulent protection for a longer period of time, especially in older seedlings.

Leaf age also may have influenced the ease of pathogen establishment. In cultivar Keitt we found that older leaves were less susceptible to anthracnose than younger leaves. We demonstrated that treatments of three-month-old mango seedlings with hypovirulent isolates (i.e., under shade-house conditions) did result in significant lesion-size reductions. These findings, however, were not reproducible with twoyear-old Keitt seedlings (Lugo Noel, 2001).

The potential of $\mathrm{HV}$ isolates in the management of anthracnose in mango was proved by the findings in this research. However, further studies are needed on the induction of mango defense mechanisms, stability of the properties of the isolates and validation of the induced protection in the field.

\section{LITERATURE CITED}

Arauz, L. F, 2000. Mango anthracnose: economic impact and current options for integrated pest management. Plant Dis. 86(6):600-611.

Anderson, A. J., 1991. Phytoalexins and Plant Resistance. In: Sharma, R. P. and D. K. Salunkhe (eds.). Mycotoxins and Phytoalexins. pp. 569-594. CRC Press, Boca Raton, FL.

Bailey, J. A. and M. J. Jeger, 1992. Colletotrichum: Biology, Pathology and Control. CABI, Int'l., Wallingford, UK.

Colón Garay, J. and L. I. Rivera Vargas, 1997a. Characterization of Colletotrichum gloeosporioides monosporic isolates from three mango (Mangifera indica L.) varieties. Proc. Annual Meeting, American Phytopathological Society-Caribbean Division. San José, Costa Rica (Abst.).

Colón Garay, J. and L. I. Rivera Vargas, 1997b. Isolation and cross inoculation of Colletotrichum spp. Sigma Xi Poster Day II. University of Puerto Rico. Mayagüez Campus (Abst.).

Colón Garay, J. and L. I. Rivera Vargas, 1998. Monosporic variation of Colletotrichum gloeosporioides isolated from mango, Mangifera indica. Proc. Annual Meeting of the Mycological Society of America, San Juan, PR (Abst.).

Dickman, M. B. and S. S. Patil, 1986. Cutinase deficient mutants of Colletotrichum gloeosporioides are nonpathogenic to papaya fruits. Physiol. Molec. Plant Pathol. 28:235-242. 
Droby, S., D. Prusky, B. Jacoby and A. Goldman, 1987. Induction of antifungal resorcionols in flesh of unripe mango fruits and its relation to latent infection by Alternaria alternata. Physiol. Molec. Plant Path. 30:285-292.

Droby, S., D. Prusky, B. Jacoby and A. Goldman, 1986. Presence of antifungal compounds in the peel of mango fruits and their relation to latent infections of Alternaria alternata. Physiol. Molec. Plant Path. 29:173-183.

Freeman, S., 2000. Genetic diversity and host specificity of Colletotrichum species on various fruits. In: Prusky, D., S. Freeman and M. B. Dickman (eds.). Colletotrichum: Host specificity, pathology and host-pathogen interaction. APS Press, St. Paul, MN. pp. 131-144.

Freeman, S., T. Katan and E. Shabi, 1998. Characterization of Colletotrichum species responsible for anthracnose diseases of various fruits. Plant Dis. 82(6):596-605.

Hammerschmidt, R. and J. Kuc, 1982. Lignification as a mechanism for induced systemic resistance in cucumber. Physiol. Plant Path. 20:61-71.

Hammond-Kosack, K. E. and J. D. G. Jones, 1996. Resistance gene-dependent plant defense responses. The Plant Cell 80:1773-1791.

Hegnauer, R., 1993. Phytochemistry and chemotaxonomy of the Anacardiaceae with special emphasis on Mangifera. In: Kostermans, A. and J. M. Bompard (eds.). The mangoes: their botany, nomenclature, horticulture and utilization. Academic Press, N.Y. pp. 11-14.

Karba, R. and J. Kuc, 1999. Induced Resistance Against Pathogens and Herbivores: An Overview. In: Agrawal, A., S. Tuzun and E. Bent (eds.). Induced Plant Defenses Against Pathogens and Herbivores. APS Press, St. Paul, MN. pp. 1-16.

Kloepper, J. W., S. Tuzun and J. Kuc, 1992. Proposed definitions related to induced resistance. Biocontrol Science and Technology. 2:349-351.

Lugo Noel, Y., 2001. Manejo de Colletotrichum spp. en mangó (Mangifera indica L.) mediante métodos biológicos y químicos. M.S. Thesis.University of Puerto Rico, Mayagüez, $66 \mathrm{pp}$.

Ploetz, R. C., 1994. Anthracnose. In: Ploetz, R. C., G. A. Zentmeyer, W. T. Nishijima, K. G. Rohrbach and H. D. Ohr (eds.). Compendium of tropical fruit diseases. APS Press, St. Paul, MN. pp. 35-36.

Prusky, D. and N. Keen, 1993. Involvement of preformed antifungal compounds in the resistance of subtropical fruits to fungal decay. Plant Dis. (77)2:114-119.

Prusky, D., I. Kobiler, R. Ardi, D. Beno-Moalem, N. Yacoby and N. Keen, 2000. Resistance mechanisms of subtropical fruits to Colletotrichum gloeosporioides. In: Prusky, D., S. Freeman and M. B. Dickman (eds.). Colletotrichum: Host specificity, pathology and host-pathogen interaction. APS Press, St. Paul, MN. pp. 232-244.

Prusky, D., S. Freeman, R. Rodríguez and N. Keen, 1994. A nonpathogenic mutant strain of Colletotrichum magna induces resistance to $C$. gloeosporioides in avocado fruits. MPMI 7(3):326-333.

Puerto Rico's Department of Agriculture, 2000. Ingreso Bruto Agrícola: cifras revisadas 1998-1999 y preliminares 1999-2000. San Juan, PR. p. 21.

Sticher, L., B. Mauch-Mani and J. P. Metraux, 1997. Systemic acquired resistance. Ann. Rev. Phytopathol. 35:235-270.

Wei, G., J. W. Kloepper and S. Tuzun, 1996. Induced systemic resistance to cucumber diseases and increased plant growth by plant growth promoting rhizobacteria under field conditions. Phytopathology. 86:221-224.

Yakoby, N., R. Zhou, I. Kobiler, A. Dinoor and D. Prusky, 2001. Development of Colletotrichum gloeosporioides restriction enzyme-mediated mutants as biocontrol agents against anthracnose disease in avocado fruits. Phytopathology 91:143-148. 